\title{
Research and Applications of the Innovative Ideological and Political Education for College Students based on Internet Technology
}

\author{
Kai $\mathrm{Ma}^{1}$ \\ Henan Agricultural University
}

\begin{abstract}
With the continuous development of the information technology, the Internet technology is exerting more prominent influence on the college students' ideological and political education. Finding a way to effectively innovate traditional ideological and political education through advanced technology and measures to adapt to developments in the new era is one of the important issues that need to be solved urgently for the current ideological and political education of college students. This paper, by questionnaires, analyzed the opportunities and challenges brought by Internet technology to college students' ideological and political education. It concludes that Internet technology provides a new educational concept and learning platform for college students' ideological and political education, and promotes the college students' ability improvement. On the other hand, there are also problems such as the lack of personalized teaching and imperfect Internet platform construction for ideological and political education. Therefore, it is necessary to strengthen the innovation of college students' ideological and political education by guiding the digitalization of the ideological and political education resources, transforming educational concepts and methods, and constructing a new platform for ideological and political education. This research is of high practical significance and value with a broad research prospect.
\end{abstract}

\section{Keywords}

Internet Technology • College Students' Ideological and Political Education • Innovative Education

\footnotetext{
${ }^{1}$ Correspondence to: Kai Ma (PhD), School of Marxism, Henan Agricultural University, Zhengzhou 450002, China. Email: 631603677@qq.com

Citation: Ma, K. (2018). Research and Applications of the Innovative Ideological and Political Education for College Students based on Internet Technology. Educational Sciences: Theory \& Practice, 18(5), 2462-2469. http://dx.doi.org/10.12738/estp.2018.5.146
} 
As the information technology keeps progressing, Internet technology has been widely used in various fields of society, and the freedom, openness and individualization of Internet has been increasingly imposing influence on the ideological and political education of college students (Hsiao, Lee, Huang, Chen \& Chen, 2006). While Internet technology brings great opportunities to college students' ideological and political education, it also brings many problems and challenges. Therefore, under the background of the continuous development of Internet technology, the improvement and innovation of college students' ideological and political education have become a widespread concern in the society (Cain, Scott \& Akers, 2009). How to effectively innovate traditional ideological and political education with advanced technology and means to adopt to the new era is one of the important issues that need to be solved urgently in the current ideological and political education of college students.

At present, many domestic and foreign experts and scholars in the education field have conducted a lot of researches on the innovation of traditional ideological and political education, but they all focus on the "Ideological and Political Education + Internet" based on network carriers (Wallman et al., 2012), with few innovative studies on ideological and political education for college students based on Internet technology. This paper analyzed the opportunities and challenges brought by Internet technology to college students' ideological and political education through questionnaires, and proposed innovative methods. Therefore, this research has broad prospects with high practical significance and value.

\section{Survey and Analysis of College Students' Ideological and Political Education}

\section{Distribution of Questionnaires}

In order to fully understand the status quo of college students' ideological and political education based on Internet technology, a questionnaire was designed in this research to survey college students nationwide, and the "online + line" model was adopted to ensure the wide coverage of the sample. In addition to on-site survey, the Internet technology was used to distribute questionnaires QR codes and web links. A total of 1364 questionnaires were collected, of which 1360 were valid and 4 were invalid. The basic information of the respondents is shown in Table 1 and Figure 1.

Table 1

Gender and Grade Composition of Respondents

\begin{tabular}{llcc}
\hline & Classification & Number & Proportion \\
\hline \multirow{2}{*}{ Gender } & Male & 764 & $56.18 \%$ \\
& Female & 596 & $43.82 \%$ \\
& Freshman & 296 & $21.76 \%$ \\
\multirow{5}{*}{ Grade } & Sophomore & 274 & $20.15 \%$ \\
& Junior & 278 & $20.44 \%$ \\
& Senior & 214 & $15.74 \%$ \\
& Graduate student & 298 & $21.91 \%$ \\
\hline
\end{tabular}




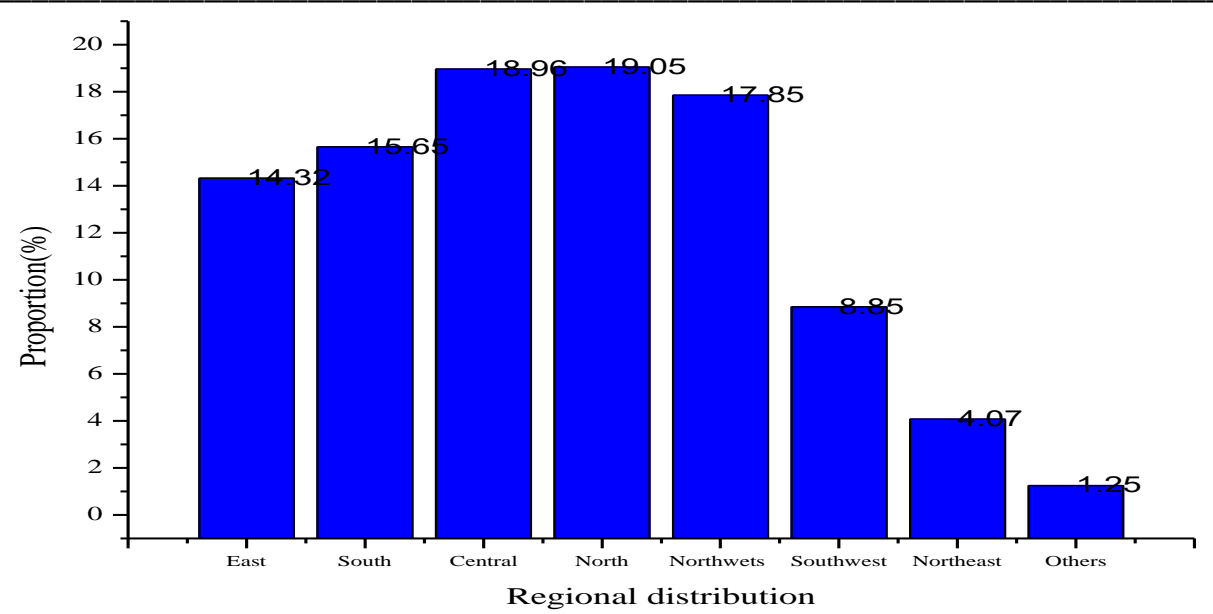

Figure 1. Regional distribution of respondents.

During the questionnaire collection, the online questionnaire submission rate was found to be $100 \%$, which indicates that the practical coverage of mobile phone, computer and other network technologies among college students is very high.

\section{Internet technology brings opportunities for college students' ideological and political education}

Through the feedback of questionnaires from college students, it can be found that Internet technology provides a new educational concept and learning platform for college students' ideological and political education, which promotes the improvement of college students' ability, and college students hope to communicate through the Internet.

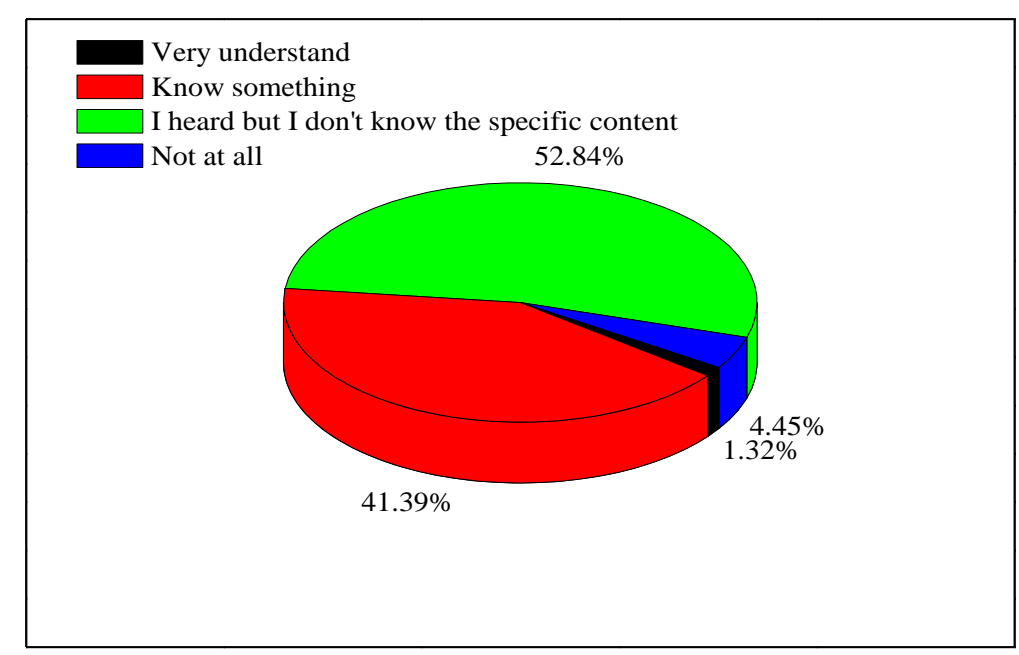

Figure 2. College students' understanding of Internet technology. 
College students prefer communication through the Internet. With the network, computer, mobile phone, etc., college students can learn about major events at home and abroad without leaving home, communicate with the outside world, and express their opinions. In the survey, it was found that most of the students have heard or understood Internet technology (see Figure 2). Regarding the necessity of adding the Internet technology into the ideological and political education, 52.75\% of the students was supportive while only $1.79 \%$ indicated no need or whatever attitude (see Figure 3 for details). This fully demonstrates that college students are highly expecting the introduction of Internet technology in ideological and political education.

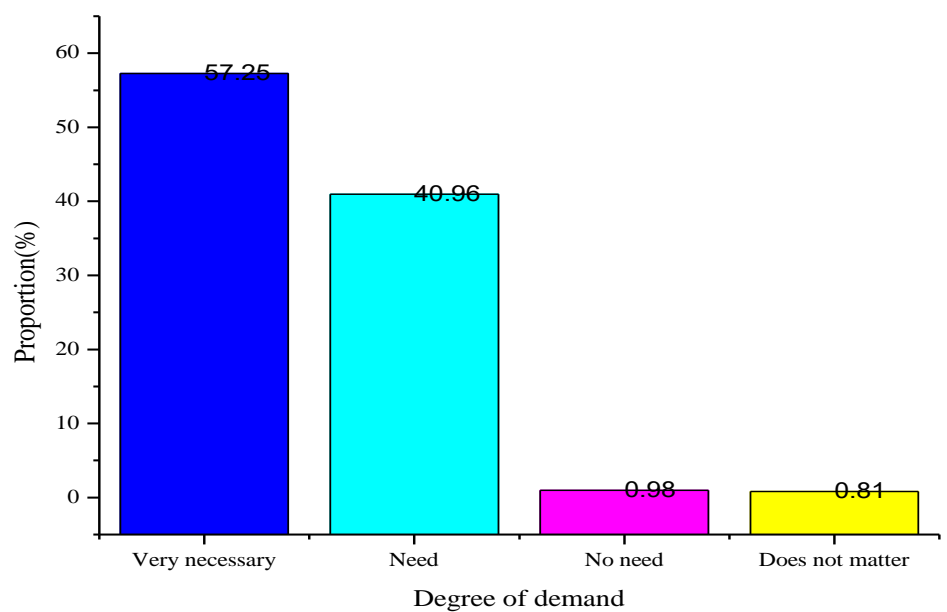

Figure 3. Questionnaire on the need of college students for "Internet + ideological and political education".

When asked about the form of ideological and political teaching in their hope, more students prefer Internet technology and even virtual classrooms, because the online platform enables instant communication with teachers at any time and eases the tension in face-to-face class. Only $7.56 \%$ of students chose the traditional way of teaching (see Figure 4 for details).

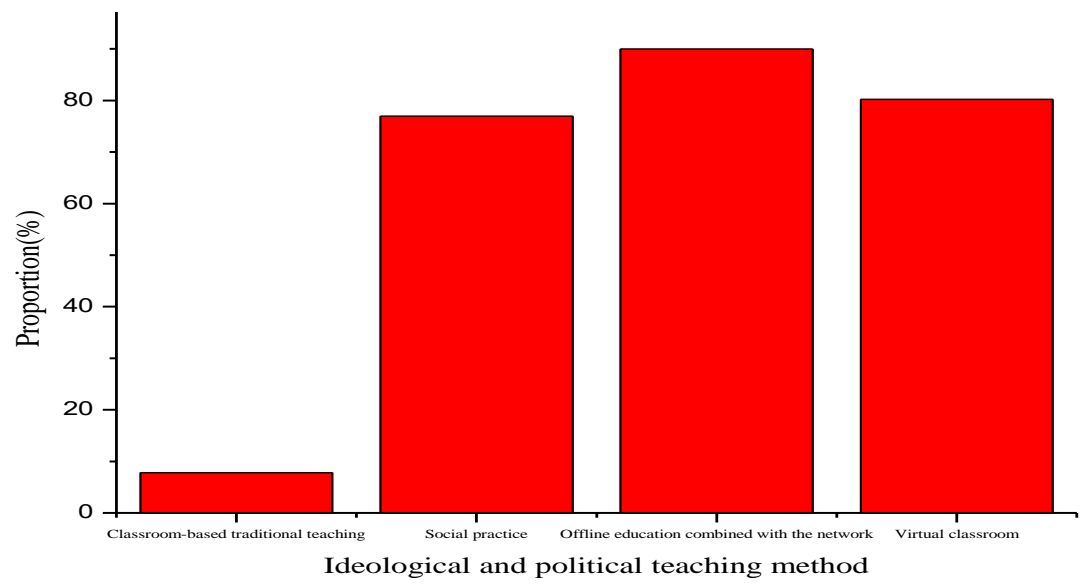

Figure 4. A survey of the teaching methods of ideological and political theory courses that college students prefer. 
The educational concept is updated. The period of rapid development of Internet technology in China matches the growth of college students born after 1996-1997, for which they have enjoyed the convenience and intelligence enabled by Internet technology since their childhood. The rapid development and wide application of Internet technology have exerted a profound impact on the current ideological and political education of college students, especially in the concept of education, which has greatly challenged traditional teaching concepts (Taylor \& Berry, 2011). The teaching and interaction between teachers and students is no longer limited by time and space, and equal communication and exchanges can be realized through Internet technology. Teachers gradually shifted their role from education leader to a guider, while students also transformed their attitudes from passive learning to actively acquiring knowledge (Gielen, 2010).

Internet technology provides a broader learning platform. College students currently prefer to shop, chat, and learn through the Internet, because on virtual networks, college students can break through the traditional constraints to express themselves. On the other hand, the openness of the Internet enhances the opportunities and spaces for exchanges between college students and presents more social fields, so that college students can learn on a broader platform and accumulate social knowledge (Reiss, 2009).

\section{Challenges Brought by Internet Technology to College Students' Ideological and Political Education}

Internet technology, though benefiting college students' ideological and political education, poses some challenges, such as the lack of personalized teaching and inadequate Internet platform construction for ideological and political education.

Imperfect construction of Internet platform for ideological and political education. Although many colleges and universities pay more and more attention to online education, the construction of the Internet platform of ideological and political education is not ideal (Olival freire, 2003). According to the survey results in Table 2,71.74\% of the students believed that there were no online live-streaming classes in the universities, and $50.51 \%$ of the students held that the universities rarely conducted online learning or discussion on hot topics. Although many colleges and universities have established platforms, the applications are limited in scope with low iteration speed, resulting in low applicable value. Therefore, the construction of the Internet platform for ideological and political education in universities needs to be strengthened (Hadzigeorgiou \& Schulz, 2014).

Table 2

A Survey of Internet Ideological and Political Education in Universities

\begin{tabular}{|c|c|c|c|c|}
\hline & Frequently & Occasionally & Rarely & Hardly \\
\hline $\begin{array}{l}\text { Network Civilization Standardized } \\
\text { Education }\end{array}$ & $96(7.06 \%)$ & $384(28.24 \%)$ & $406(29.85 \%)$ & $474(34.85 \%)$ \\
\hline $\begin{array}{l}\text { The study of the red website, the } \\
\text { discussion of hot topics on the internet, } \\
\text { etc }\end{array}$ & $105(7.72 \%)$ & $503(36.99 \%)$ & $687(50.51 \%)$ & $65(4.78 \%)$ \\
\hline Theme Network Essay Contest & $184(13.53 \%)$ & $798(58.68 \%)$ & $312(22.94 \%)$ & $66(4.85 \%)$ \\
\hline $\begin{array}{l}\text { Face - to - face live webcast class with } \\
\text { famous teachers }\end{array}$ & $96(7.06 \%)$ & $207(15.22 \%)$ & $85(6.25 \%)$ & $972(71.47 \%)$ \\
\hline
\end{tabular}

Lack of personalized teaching content. As for the reasons for college students' less attention for the universities' online ideological and political education platforms, the survey found that the most important 
reason was the lack of personalized services, accounting for $52.19 \%$. In addition, $35.64 \%$ of the student held that the content was not vivid but only rigid; $28.96 \%$ of the students held that the content was update too slowly; $25.74 \%$ of the students held that the universities looked down on publicity (see Figure 5 for details).

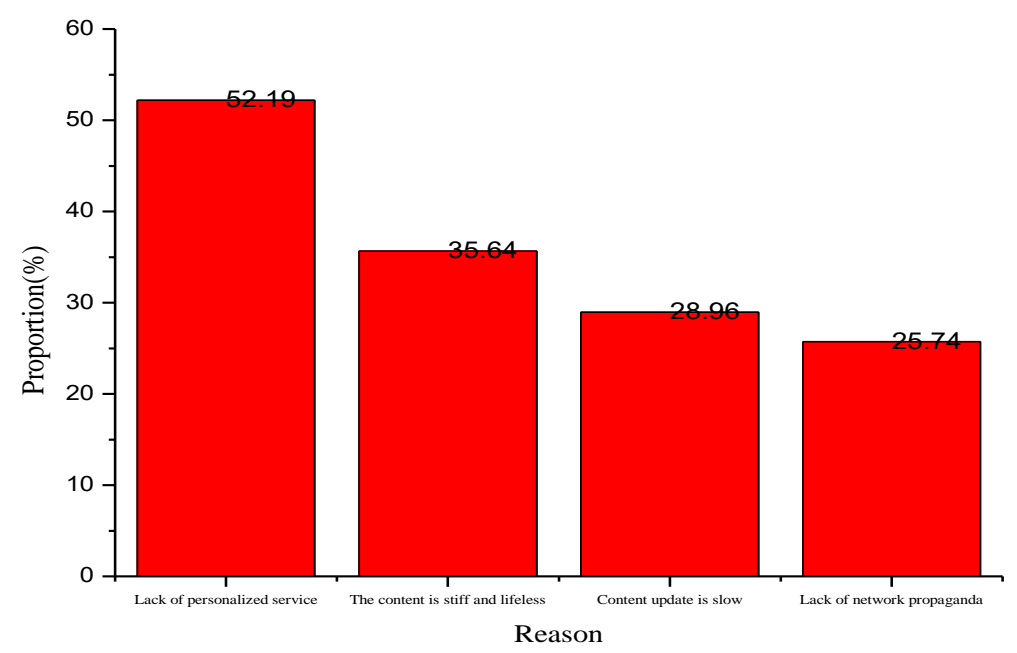

Figure 5. A survey of reasons for college students' believing that the click rate of ideological and political education network platform is not high.

\section{Application of Internet Technology in College Students' Ideological and Political Education}

\section{Guide the digitalization of ideological and political education resources}

The development of Internet technology broke the conventional textbook-based ideological and political education model, and has gradually digitalized the educational resources such as PPT, video, flash animation, test question bank, etc. The digital teaching mode can free students from the boring and tedious textbook learning, and enhance their hands-on ability in knowledge acquisition (Memon, 2011). In addition, a variety of digital teaching modes and platforms can be integrated to improve diversity.

\section{Transform educational concepts and methods}

Under the guidance of Internet technology, the ideas and methods of ideological and political education have changed. Teachers no longer instill ideas into students through simple preaching education, but students now take the initiative to learn. The evaluation of learning effects is no longer merely an assessment of scores, but follows a more diversified, more comprehensive and more humane evaluation criteria. Internet technology enables students to interact with other students from all over the world, and enhances the effectiveness of ideological and educational education (Hadzigeorgiou, 2015).

\section{Build a new platform for ideological and political education work}

The ideological and political education of college students is a systematic project. It should not be limited to traditional classroom education, but should be based on Internet technology to provide comprehensive 
$\overline{\text { education for college students. Specifically, universities shall strengthen the network construction, use WeChat }}$ and Weibo to establish an exchange platform for equal dialogue between students and teachers, analyze the effectiveness of college students' ideological and political education through big data, and supervise ideological and political education through online media.

\section{Conclusion}

This paper analyzed the opportunities and challenges brought by Internet technology to college students' ideological and political education through questionnaires, and studied the innovative methods of college students' ideological and political education based on Internet technology. The following conclusions were drawn:

(1) Through survey and analysis, it is found that Internet technology provides a new educational concept and learning platform for college students' ideological and political education, which promotes the improvement of college students' ability. On the other hand, some problems exist such as the lack of personalized teaching and ideological and imperfect construction of the online platform for ideological and political education.

(2) The application of Internet technology in the innovation of college students' ideological and political education shall be strengthened by guiding the digitalization of the ideological and political education resources, transforming educational concepts and methods, and establishing a new platform for ideological and political education.

\section{References}

Cain, J., Scott, D. R., \& Akers, P. (2009). Pharmacy students' Facebook activity and opinions regarding accountability and e-professionalism. American Journal of Pharmaceutical Education, 73(6), 104. http://dx.doi. org/10.5688/aj7306104

Gielen, P. (2010). Educating art in a globalizing world. the university of ideas: A sociological case-study. International Journal of Art \& Design Education, 25(1), 5-15. http://dx.doi. org/10.1111/j.14768070.2006.00464.x

Hadzigeorgiou, Y., \& Schulz, R. (2014). Romanticism and romantic science: Their contribution to science education. Science \& Education, 23(10), 1963-2006. http://dx.doi. org/10.1007/s11191-014-9711-0

Hadzigeorgiou, Y. (2015). A critique of science education as sociopolitical action from the perspective of liberal education. Science \& Education, 24(3), 259-280. http://dx.doi. org/10.1007/s11191-014-9728-4

Hsiao, F. Y., Lee, J. A., Huang, W. F., Chen, S. M., \& Chen, H. Y. (2006). Survey of medication knowledge and behaviors among college students in Taiwan. American Journal of Pharmaceutical Education, 70(2), 30. http://dx.doi. org/10.5688/aj700230

Memon, N. (2011). What Islamic school teachers want: Towards developing an Islamic teacher education programme. British Journal of Religious Education, 33(3), 285-298. http://dx.doi. org/10.1080/01416200.2011.595912 
Ma / Research and Applications of the Innovative Ideological and Political Education for...

Olival freire, J. R. (2003). A story without an ending: The quantum physics controversy 1950 1970. Science \& Education, 12(5-6), 573-586. http://dx.doi. org/10.5040/9781472599858.ch-004

Reiss, M. J. (2009). Imagining the world: The significance of religious worldviews for science education. Science \& Education, 18(6-7), 783-796. http://dx.doi. org/10.1007/s11191-007-9091-9

Taylor, C. T., \& Berry, T. M. (2011). A pharmacy faculty academy to foster professional growth and long-term retention of junior faculty members. American Journal of Pharmaceutical Education, 72(2), 32. http://dx.doi. org/10.5688/aj720232

Wallman, A., Sporrong, S. K., Gustavsson, M., Lindblad, Å. K., Johansson, M., \& Ring, L. (2011). Swedish students' and preceptors' perceptions of what students learn in a six-month advanced pharmacy practice experience.American Journal of Pharmaceutical Education,75(10), 197. http://dx.doi. org/10.5688/ajpe7510197 